\title{
Neutrophil Elastase in Respiratory Epithelial Lining Fluid of Individuals with Cystic Fibrosis Induces Interleukin-8 Gene Expression in a Human Bronchial Epithelial Cell Line
}

\author{
Hidenori Nakamura, Kunihiko Yoshimura, Noel G. McElvaney, and Ronald G. Crystal \\ Pulmonary Branch, National Heart, Lung, and Blood Institute, National Institutes of Health, Bethesda, Maryland 20892
}

\begin{abstract}
The respiratory manifestations of cystic fibrosis (CF) are characterized by neutrophil-dominated airway inflammation. Since a variety of inflammatory stimuli are capable of inducing bronchial epithelial cells to express the gene for IL-8, a cytokine that attracts and activates neutrophils, mediators in respiratory epithelial lining fluid (ELF) of CF individuals might induce IL-8 production by epithelial cells, thus recruiting neutrophils to the airways. BET-1A human bronchial epithelial cells at rest or incubated with normal ELF showed little IL-8 gene expression, but after incubation with CF ELF, a marked increase in IL-8 transcript levels was observed. CF ELF contained high levels of neutrophil elastase (NE) and various serine protease inhibitors prevented CF ELF from inducing IL-8 gene expression in BET-1A cells, suggesting that NE was the dominant inducer for IL-8 production in CF ELF. The addition of purified NE caused BET-1A cells to increase IL-8 gene transcription with accumulation of mRNA transcripts and to release IL-8like neutrophil chemotactic activity. These observations suggest a self-perpetuating inflammatory process on the CF bronchial surface where NE released by neutrophils induced the bronchial epithelium to secrete IL-8, which in turn recruits additional neutrophils to the bronchial surface. (J. Clin. Invest. 1992. 89:1478-1484.) Key words: cytokine • anti-serine protease $\bullet$ bronchial epithelium $\bullet$ neutrophil chemoattractant $\bullet$ airway inflammation
\end{abstract}

\section{Introduction}

Cystic fibrosis (CF) ${ }^{1}$ is a lethal hereditary disorder caused by mutations of the cystic fibrosis transmembrane conductance regulator (CFTR) gene, a $250 \mathrm{~kb}, 27$ exon gene on chromosome 7 (1-4). The CFTR gene product, a 168-kD glycosylated membrane protein, is thought to function as a chloride channel regulated by cytoplasmic protein kinases (3, 5-9). Although the link between mutations in the CFTR gene and the pathogenesis of CF are not completely understood, the lethal clinical manifestations of CF are clearly related to the thick, infected

1. Abbreviations used in this paper: AAPV-CMK, methoxy-succinylalanyl-alanyl-prolyl-valyl-chloromethyl-ketone; CF, cystic fibrosis; CFTR, CF transmembrane conductance regulator; ELF, epithelial lining fluid; NE, neutrophil elastase; SLPI, secretory leukoprotease inhibitor.

Address reprint requests to Ronald G. Crystal, M.D., Pulmonary Branch, Building 10, Room 6D03, National Institutes of Health, Bethesda, MD 20892.

Received for publication 11 June 1991 and in revised form 13 December 1991.

The Journal of Clinical Investigation, Inc.

Volume 89, May 1992, 1478-1484 mucus and chronic neutrophil-dominated inflammation on the epithelial surface of the airways (1, 10-14). The large numbers of neutrophils place the airway epithelium in great jeopardy consequent to the exposure to potent neutrophil mediators, including neutrophil elastase, reactive oxygen species, and probably a variety of cytokines (10-14). Over time, this potent armamentarium overwhelms the local defense of the epithelium, resulting in damage and derangement of the airways (1, 13, 15-19).

In this context, it is apparent that recruitment of neutrophils to the bronchial surface is a two-edged sword, necessary to contend with the local infection, but dangerous to the vulnerable epithelium. While it is not clear whether the numbers of neutrophils that are recruited are appropriate for the level of infection, in excess, or insufficient for host defense, it is relevant to ask the question: what signals the neutrophils to accumulate on the respiratory epithelial surface in CF? The answer is likely complex, and undoubtedly involves a variety of mechanisms, including chemoattractants released by alveolar macrophages as well as those linked to the complement system (13, 14, 20-24). The present study was designed to expand these concepts to include bronchial epithelial cells as a source of chemoattractants for neutrophils. Based on the knowledge that human bronchial epithelial cells can release the potent neutrophil chemoattractant IL-8 in response to a variety of stimuli (25-28), we hypothesized that the epithelial lining fluid (ELF) of individuals with CF contains signals capable of inducing the expression of the IL-8 gene in bronchial epithelial cells. The data demonstrate that CF ELF does contain such signals, and interestingly, the dominant signal is neutrophil elastase (NE), suggesting a cycle of inflammation on the respiratory epithelium in CF, to where neutrophils are attracted and NE is released, resulting in induction of expression of IL- 8 by the respiratory epithelium, and the recruitment of more neutrophils.

\section{Methods}

Study population. The study population included eight individuals with cystic fibrosis (four male, four female; average age of $28 \pm 2$ yr [all data are expressed as mean \pm standard error of the mean; all statistical comparisons were done with the two-tailed Student's $t$ test]). All had a positive sweat chloride test, chronic sputum production, respiratory tract colonization with Pseudomonas aeruginosa, and moderate impairment of lung volumes and flow rates (as percentage predicted FEV $41 \pm 4$, FVC 52 \pm 5$)(1,29)$. The average Shwachman score was $56 \pm 6$ (30). All were lifelong nonsmokers. As a control, seven normal nonsmoking individuals were evaluated (four male, three female; average age of $29 \pm 3 \mathrm{yr}$ ). None had a history of pulmonary symptoms and all had normal physical examination, chest roentgenograms, and lung function tests.

Recovery of respiratory epithelial lining fluid. Bronchoalveolar lavage was used to obtain the respiratory ELF as previously described (31). Cells were isolated from the fluid by centrifugation, and total and 
differential cell counts determined. ELF volumes were quantified by the urea method (32). The fluid was maintained at $-70^{\circ}$ until evaluated.

Neutrophil elastase, neutrophil elastase inhibitors, and IL-8. NE activity in ELF was quantified using the NE-specific substrate methoxy-succinyl-alanyl-alanyl-prolyl-valyl-nitroanalide (Sigma Chemical Co., St. Louis, MO) as previously described (33). Purified NE (Elastin Products Co., Inc., Pacific, MO) was titrated against a purified human $\alpha 1$-antitrypsin ( $\alpha 1 \mathrm{AT}$ ) active standard (33). Serine protease inhibitors used as inhibitors of NE in this study included human recombinant secretory leukoprotease inhibitor (SLPI; Synergen, Boulder, CO), human plasma $\alpha 1 \mathrm{AT}$ (Calbiochem Corp., La Jolla, CA), PMSF (Calbiochem), and the NE-specific inhibitor methoxy-succinyl-alanyl-alanylprolyl-valyl-chloromethyl ketone (AAPV-CMK; Sigma). All inhibitors were tested in vitro for their activity in inhibiting NE as previously described (33). IL-8 levels in ELF were measured using an enzymelinked IL-8 immunoassay (Quantikine; R\&D Systems, Minneapolis, $M N)$. The effect of NE on the form of IL-8 was evaluated with Western analysis of IL-8 incubated with varying concentrations of NE (ranging from $10 \mathrm{nM}$ to $10 \mu \mathrm{M}$ ) similar to that found in CF ELF, using 15\% SDS polyacrylamide gel electrophoresis and a polyclonal anti-human IL-8 antibody (Biosource International, Westlake Village, CA).

Cell cultures. BET-1A cells, an SV40 transformed human bronchial epithelial cell line (gift of J. E. Lechner, Laboratory of Human Carcinogenesis [LHC], National Cancer Institute) were cultured at $37^{\circ}$ in serum-free LHC- 9 medium with $25 \mu \mathrm{g} / \mathrm{ml}$ fungizone, $25 \mathrm{U} / \mathrm{ml}$ penicillin, and $25 \mu \mathrm{g} / \mathrm{ml}$ streptomycin (all from Biofluids Inc., Rockville, MD) (34). The surface of the culture dishes were coated with a mixture of human fibronectin $(10 \mu \mathrm{g} / \mathrm{ml}$; Collaborative Research Inc., Bedford, MA), collagen (Vitrogen $100,30 \mu \mathrm{g} / \mathrm{ml}$; Collagen Corp., Palo Alto, CA), and crystallized BSA ( $10 \mu \mathrm{g} / \mathrm{ml}$; Biofluids) dissolved in LHC basal medium (Biofluids) (35). All studies were carried out when the cells were $80-90 \%$ confluent.

IL-8 mRNA transcript levels. The levels of IL-8 mRNA transcripts and control $\beta$-actin mRNA transcripts were evaluated by Northern analysis and by slot blot hybridization $(36,37)$. Total cellular RNA was isolated by the guanidinium thiocyanate- $\mathrm{CsCl}$ gradient method (38). For Northern analyses, RNA ( $10 \mu \mathrm{g} /$ lane $)$ was subjected to agarose gel electrophoresis and transferred to a nylon membrane (Nytran; Schleicher and Schuell Inc., Keene, NH). The filter was hybridized with probes labeled with ${ }^{32} \mathrm{P}$ by the random priming method $(39,40)$. The IL-8 probe was a 750-bp cDNA derived from clone pPB248 containing the sequence from the PstI site of exon I to the BamHI site of exon IV (25). It was constructed after reverse transcription of RNA from lipopolysaccharide (Escherichia coli 0127:B8; Difco Laboratories, Detroit, MI) stimulated human blood monocytes followed by amplification of IL-8 cDNA using the polymerase chain reaction with IL-8 exon-specific oligonucleotide primers (NAFS1, 5'-ATTTCTGCAGCTCTGTGTGAAGGTGC-3'; and NAFAS2, 5'-TTGTGGATCCTGGCTAGCAGAC- $\left.3^{\prime}\right)(25,41-43)$. As a control $\beta$-actin probe, the cDNA clone pHF $\beta A-1$ was used (44). For normal and CF ELF studies and NE dose-dependence and time-course studies, mRNA transcript levels were quantified by slot blot hybridization analysis and densitometry (Ultroscan Laser Densitometer; Pharmacia LKB, Piscataway, NJ) using $10 \mu \mathrm{g}$ RNA as the starting material and the IL-8 and $\beta$-actin probes described above.

Modulation of IL-8 mRNA transcript levels. Based on prior observations that tumor necrosis factor- $\alpha$ (TNF) induced BET-1A cells to express the IL-8 gene (25), human recombinant TNF $(200 \mathrm{U} / \mathrm{ml}, 20$ $\mathrm{U} / \mathrm{ng}$; Genzyme Corp., Boston, MA) was used as a positive control and prototype inflammatory stimulus. In parallel cultures, respiratory ELF ( $1 \mu \mathrm{l} \mathrm{ELF/ml} \mathrm{culture} \mathrm{media)} \mathrm{from} \mathrm{normals} \mathrm{and} \mathrm{individuals} \mathrm{with} \mathrm{CF}$ were added to the cell culture, incubated for $3 \mathrm{~h}$ at $37^{\circ}$, and IL-8 and $\beta$-actin mRNA levels evaluated by Northern or slot blot analysis.

To determine the nature of the signals in CF ELF that induced BET-1A cells to express the IL-8 gene, the CF ELF was incubated for 10 $\min , 37^{\circ}$ alone, or in the presence of the various protease inhibitors, including rSLPI $(500 \mathrm{nM}), \alpha 1 \mathrm{AT}(500 \mathrm{nM}), \operatorname{PMSF}(1 \mu \mathrm{M})$, or AAPV-
CMK $(1 \mu \mathrm{M})$. In parallel cultures, the mouse monoclonal anti-human TNF antibody (Genentech, Inc., South San Francisco, CA) was added. Based on the observation that the serine protease inhibitors prevented CF ELF from inducing IL-8 gene expression in the BET-1A cells, the studies were also carried out using purified $\mathrm{NE}$ alone or incubated with protease inhibitors in a similar fashion before their addition to the cell culture. The dose-dependent studies with NE were carried out using $0-50 \mathrm{nM}$ of purified NE for $3 \mathrm{~h}$. The time-course studies used $10 \mathrm{nM}$ of NE and subsequent incubation of the BET-1A cells for 0-24 h. The dose and time-course studies were complicated by the effect of NE on detaching cells from the culture plate observed at concentrations of $\mathrm{NE}$ $>50 \mathrm{nM}$ or incubation with $10 \mathrm{nM}$ for $>24 \mathrm{~h}$, and these effects were limited to these conditions and times. Cell viability assessed by trypan blue dye exclusion was $>95 \%$ in all studies.

$I L-8$ release by neutrophil elastase-stimulated BET- $1 A$ cells. To demonstrate that NE induces bronchial epithelial cells to release functional IL-8, neutrophil chemotactic activity in the culture supernatants was evaluated from resting and NE-stimulated BET-1A cells as well as in ELF from individuals with CF and normal individuals using a modified Boyden chamber (45). Neutrophils were isolated ( $>95 \%$ pure) from blood of normal individuals by centrifugation through MonoPoly-Resolving medium (Flow Laboratories, Irvine, CA) (46) and resuspended in Hanks' balanced salt solution (Mediatech, Herndon, VA) at $2 \times 10^{6} \mathrm{cells} / \mathrm{ml}$. Chemotactic activity was expressed as the percentage of an FMLP $\left(10^{-7} \mathrm{M}\right.$; Sigma) positive control. Controls included culture media alone, human recombinant monocyte IL-8 $(5 \mathrm{ng} / \mathrm{ml}$; Upstate Biotechnology, Inc., Lake Placid, NY), culture media from resting cells, and NE alone. Conditioned media from NE-stimulated (10 nM) BET-1A cells (all incubations $24 \mathrm{~h}, 37^{\circ}$ ) and ELF from normals or individuals with CF were evaluated in the absence or presence of a rabbit IgG anti-IL-8 antibody or nonimmune IgG $(100 \mu \mathrm{g} / \mathrm{ml}$; Endogen, Boston, MA) and in the presence of the NE-specific inhibitor AAPV-CMK $(1 \mu \mathrm{M})$.

Level of modulation of $I L-8$ gene expression in BET-1A cells by neutrophil elastase. Modulation of the relative rate of IL-8 gene transcription by $\mathrm{NE}$ was evaluated using nuclear run-on analysis (47). $\mathrm{Nu}$ clei were isolated from $5 \times 10^{7}$ BET-1 A cells at rest, stimulated with NE $(10 \mathrm{nM})$, or with NE in the presence of $\alpha 1 \mathrm{AT}(500 \mathrm{nM})$ or SLPI (500 $\mathrm{nM})$. The nuclei were incubated with $5 \mathrm{mM}$ ATP, $2 \mathrm{mM} \mathrm{CTP,} 2 \mathrm{mM}$ UTP, $330 \mu \mathrm{Ci}\left[\alpha_{-}{ }^{32} \mathrm{P}\right]$ GTP (Amersham Corp., Arlington Heights, IL), and RNase inhibitor (RNasin, $2 \mathrm{U} / \mu \mathrm{l}$; Promega Biotec, Madison, WI) to label actively transcribed RNA. RNA was isolated by the acid guanidinum thiocyanate-phenol-chloroform method (RNAzol B; Cinna/ Biotex Laboratories International Inc., Friendwood, TX) (48). ${ }^{32} \mathrm{P}$-labeled nascent RNA was purified by Sephadex G-50 column chromatography ( 5 prime $\rightarrow 3$ prime, Inc., West Chester, PA) and hybridized to excess amounts $(5 \mu \mathrm{g})$ of DNA targets immobilized on Nytran (Schleicher and Schuell Inc.). The DNA targets included plasmids containing an IL-8 cDNA (pPB248), a partial genomic clone for c-myc (Lofstrand Labs, Gaithersburg, MD), a human $\beta$-actin cDNA (pHF $\beta A$ 1 ), or as a negative control, the plasmid pBluescript II SK + (pBS; Stratagene, Inc., La Jolla, CA). After $36 \mathrm{~h}$, the membranes were washed, exposed to RNase $A(5 \mu \mathrm{g} / \mathrm{ml})$ and RNase $T_{1}(5 \mathrm{U} / \mathrm{ml})$, followed by proteinase $\mathrm{K}(50 \mu \mathrm{g} / \mathrm{ml})$ (all from Boehringer Mannheim Biochemicals, Indianapolis, IN), and evaluated by autoradiography.

To evaluate the stability of IL-8 mRNA transcripts after NE stimulation, BET-1A cells were treated with actinomycin D $(10 \mu \mathrm{g} / \mathrm{ml}$; United States Biochemicals, Cleveland, $\mathrm{OH}$ ) for $30 \mathrm{~min}, 1,2$, and $4 \mathrm{~h}$, and the following conditions were evaluated: BET-1A cells at rest, after exposure to $\mathrm{NE}(10 \mathrm{nM}, 3 \mathrm{~h})$, or after the addition of the protein synthesis inhibitor, cycloheximide $(10 \mu \mathrm{g} / \mathrm{ml}, 3 \mathrm{~h}$; Sigma). Total cellular RNA was extracted, IL-8 mRNA levels were evaluated by Northern analysis as described above, and quantified using laser densitometry.

\section{Results}

Epithelial lining fluid in cystic fibrosis. The relative amounts of ELF recovered from individuals with CF was similar to that of 
Table I. Evaluation of Respiratory Epithelial Lining Fluid Recovered by Bronchoalveolar Lavage From Normals and Individuals with Cystic Fibrosis

\begin{tabular}{|c|c|c|c|c|c|c|c|c|c|}
\hline \multirow[b]{2}{*}{$\begin{array}{l}\text { Study } \\
\text { group }\end{array}$} & & \multirow[b]{2}{*}{$\begin{array}{l}\text { Patient no./ } \\
\text { sex/age }\end{array}$} & \multirow[b]{2}{*}{$\begin{array}{l}\text { Recovered } \\
\text { ELF }\end{array}$} & \multicolumn{4}{|c|}{ Cell numbers $\left(\times 10^{3}\right.$ cells $/ \mu 1$ ELF $)$} & \multirow[b]{2}{*}{$\begin{array}{c}\text { NE in } \\
\operatorname{ELF}(\mu \mathrm{M})\end{array}$} & \multirow[b]{2}{*}{$\begin{array}{l}\text { IL-8 in } \\
\text { ELF (nM) }\end{array}$} \\
\hline & & & & $\begin{array}{l}\text { Total } \\
\text { cells }\end{array}$ & Macrophages & Neutrophils & Lymphocytes & & \\
\hline & $n$ & & $m l$ & & & & & & \\
\hline Normal & 7 & & $1.12 \pm 0.17^{*}$ & $14.7 \pm 2.4$ & $12.5 \pm 2.0$ & $0.4 \pm 0.3$ & $1.7 \pm 0.4$ & $\mathrm{ND}^{\ddagger}$ & ND \\
\hline \multirow[t]{9}{*}{$\mathrm{CF}$} & 8 & & $0.97 \pm 0.24$ & $121 \pm 29$ & $20 \pm 4$ & $101 \pm 26$ & 0 & $31 \pm 10$ & $35 \pm 13$ \\
\hline & & $1 / F / 26$ & 0.18 & 256 & 46 & 210 & 0 & 86 & 108 \\
\hline & & $2 / \mathrm{M} / 29$ & 1.27 & 149 & 24 & 125 & 0 & 66 & 68 \\
\hline & & $3 / \mathrm{M} / 31$ & 0.74 & 245 & 25 & 221 & 0 & 30 & 38 \\
\hline & & $4 / M / 26$ & 0.75 & 55 & 33 & 51 & 0 & 7 & 11 \\
\hline & & $5 / F / 26$ & 0.27 & 37 & 8 & 29 & 0 & 9 & 16 \\
\hline & & $6 / F / 29$ & 2.52 & 107 & 15 & 92 & 0 & 18 & 17 \\
\hline & & $7 / F / 29$ & 0.91 & 73 & 22 & 51 & 0 & 7 & 8 \\
\hline & & $8 / \mathrm{M} / 22$ & 1.08 & 47 & 16 & 32 & 0 & 26 & 14 \\
\hline
\end{tabular}

Patient no., patients with CF numbered consecutively. * Mean \pm standard error or the mean. $\ddagger$ ND, not detected.

normals (Table I, $P=0.63$ ). The total numbers of inflammatory cells in ELF were markedly increased in CF, averaging more than eightfold greater than that of normals $(P<0.03)$. The increase in the number of inflammatory cells in CF ELF was dominated by neutrophils, with $>250$-fold increase over the neutrophil numbers in normal ELF $(P<0.005)$. High levels of active neutrophil elastase were readily detectable in all CF ELF samples with an average of $31 \pm 10 \mu \mathrm{M}$ (range 7-86 $\mu \mathrm{M}$ ) whereas normal ELF did not contain any active NE. Interestingly, IL-8 was present in all CF ELF with an average of $35 \pm 13$ $\mathrm{nM}$ (range 8-108 $\mathrm{nM}$ ) but was undetectable in normal ELF. Western blot analysis of the IL-8 incubated with varying amounts of NE showed no evidence of degradation of the IL-8 (not shown).

Cystic fibrosis epithelial lining fluid induced IL-8 gene expression in bronchial epithelial cells. Northern analyses demonstrated that resting BET-1A cells contained very little, if any, IL-8 mRNA transcripts (Fig. 1, lane 1). As a positive control, recombinant TNF induced expression of the expected 1.8-kb IL-8 mRNA transcripts (lane 2). Importantly, although ELF from normal individuals had no influence on IL-8 gene expres-

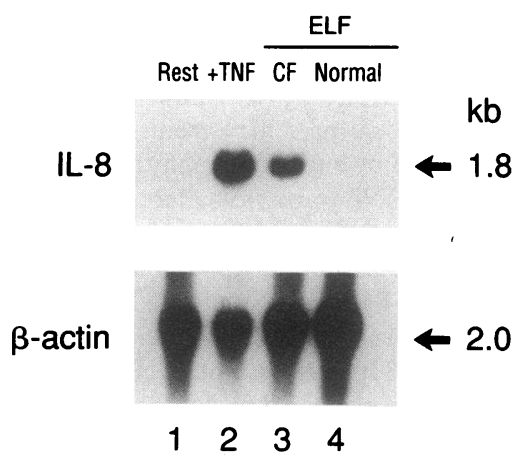

Figure 1. Induction of IL-8 gene expression by components of respiratory epithelial lining fluid $(E L F)$ in BET-1A human bronchial epithelial cells. Shown are Northern blot analyses of RNA (10 $\mu \mathrm{g} /$ lane) from resting cells (lane 1) and cells incubated $\left(3 \mathrm{~h}, 37^{\circ}\right)$ with tumor necrosis factor- $\alpha(T N F$; $200 \mathrm{U} / \mathrm{ml}$ ) (lane 2), ELF from a normal individual ( $1 \mu \mathrm{l} \mathrm{ELF} / \mathrm{ml}$ ) (lane 4), and ELF from an individual with cystic fibrosis $(C F)(1 \mu \mathrm{l} \mathrm{ELF} / \mathrm{ml})$ (lane 3). The blots were hybridized with ${ }^{32} \mathrm{P}$-labeled IL-8 cDNA probe (top) or $\beta$-actin probe (bottom). The sizes of mRNA transcripts are indicated. sion in the BET-1A cells, CF ELF induced the expression of IL-8 mRNA transcripts (lanes 3 and 4). In contrast to the difference in IL-8 mRNA transcripts when ELF from normals and individuals with CF were incubated with BET-1A cells, control $\beta$-actin mRNA transcript levels did not change (lanes 1-4).

Quantification of IL-8 mRNA levels in BET-1A cells incubated with normal or CF ELF demonstrated that ELF from the seven normal individuals did not induce IL-8 gene expression, but ELF from all eight CF individuals was capable of inducing IL-8 mRNA transcripts in BET-1A cells (Fig. $2 A$ ). In contrast to the differences in IL-8 transcripts induced by normal and CF ELF, neither ELF changed $\beta$-actin mRNA transcript levels $(B)$.

Neutrophil elastase inhibitors prevent cystic fibrosis epithelial lining fluid induction of IL-8 gene expression in bronchial epithelial cells. Based on the observations of increased numbers of neutrophils in CF ELF, active NE in CF ELF was evaluated as a possible candidate for the signal that induced IL-8 gene expression in BET-1A cells.

First, NE inhibitors were evaluated for their ability to prevent CF ELF from inducing IL-8 gene expression in BET-1A cells (Fig. 3). Northern analyses demonstrated that resting cells had no IL-8 mRNA (lane 1) while CF ELF induced IL-8 mRNA transcripts (lane 2). Importantly, NE inhibitors such as SLPI (lane 3), $\alpha 1$ AT (lane 4), PMSF (lane 5), or AAPV-CMK (lane 6) all blocked the induction of IL-8 gene expression. Further, an anti-TNF antibody did not suppress CF ELF induction of IL-8 gene expression (lane 7), although this same antibody was capable of inhibiting TNF-induced IL-8 gene expression in parallel cultures of BET-1A cells (lanes 8 and 9). In contrast to the IL-8 mRNA, $\beta$-actin gene expression did not change with any condition. Together, these observations strongly suggest that NE in CF ELF is responsible for the induction of IL-8 gene expression in the bronchial epithelial cells.

Neutrophil elastase induction of IL-8 gene expression in bronchial epithelial cells. Consistent with the hypothesis that the NE in CF ELF was the signal that upregulated IL-8 gene expression in BET-1A cells, Northern analyses demonstrated that purified NE increased IL-8 mRNA transcript levels in BET-1A cells in a similar fashion (Fig. 4, lane 1 and 2). Further, 

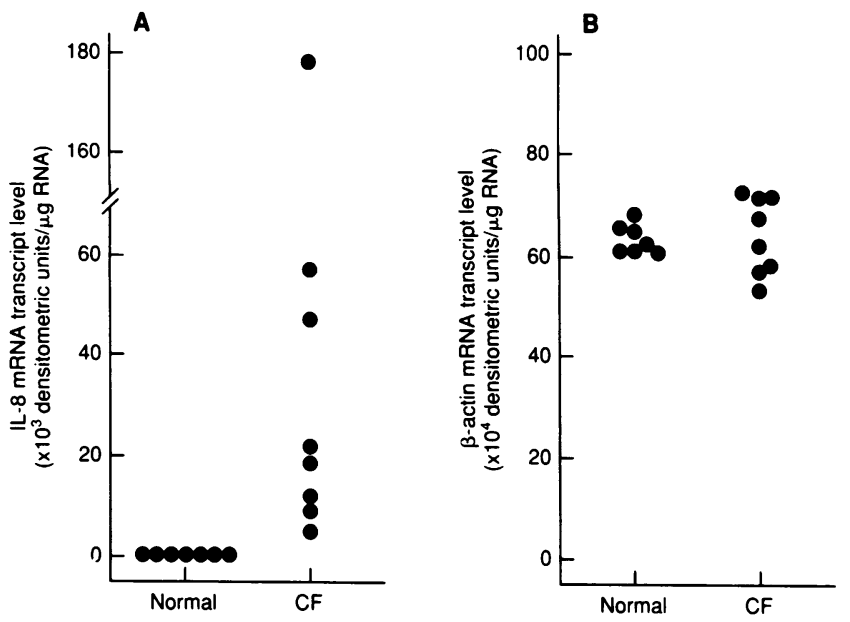

Figure 2. IL-8 and $\beta$-actin mRNA transcript levels in BET-1A human bronchial epithelial cells incubated with respiratory ELF from normals and individuals with CF. Each data point represents IL-8 $(A)$ or $\beta$-actin $(B)$ mRNA transcript levels from one individual evaluated by slot blot analyses from BET-1A cells stimulated with normal or CF ELF for $3 \mathrm{~h}$.

the effect of NE could be blocked by the addition of NE inhibitors, including SLPI (lane 3), $\alpha 1 \mathrm{AT}$ (lane 4), PMSF (lane 5), or AAPV-CMK (lane 6). Levels of control $\beta$-actin mRNA transcript were constant in all conditions. The upregulation of IL-8 mRNA transcripts by NE occurred in a dose- and time-dependent fashion (Fig. 5). IL-8 gene expression was observed at very low concentrations of $\mathrm{NE}(100 \mathrm{pM})$ and continued to increase up to $50 \mathrm{nM}(A)$. Following a fixed dose $(10 \mathrm{nM})$ of NE, IL-8 mRNA levels rapidly increased to its maximum at 3-6 h; it then decreased, but was still elevated at $24 \mathrm{~h}(B)$.

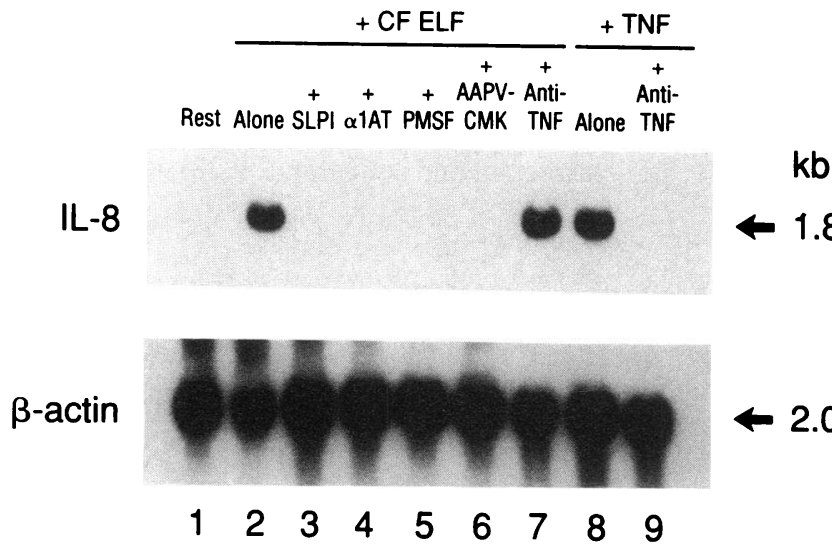

Figure 3. Suppression of the ability of respiratory ELF from individuals with CF to induce IL-8 gene expression in human bronchial epithelial BET-1A cells by inhibitors of NE. Shown are Northern analyses of total cellular RNA ( $10 \mu \mathrm{g} /$ lane) from BET-1A cells hybridized with a ${ }^{32} \mathrm{P}$-labeled IL-8 cDNA (top) or $\beta$-actin cDNA probe (bottom). The size of mRNA transcripts are indicated. Lane 1 , cells at rest; lane 2, incubated with CF $\operatorname{ELF}(1 \mu \mathrm{l} / \mathrm{ml})$; lane 3, same as lane 2, but together with recombinant SLPI; lane 4 , as lane $2,+$ plasma $\alpha 1$-antitrypsin $(\alpha 1 \mathrm{AT})$; lane 5 , as lane $2,+\mathrm{PMSF}$; lane 6 , as lane 2 + AAPV-CMK; lane 7, as lane 2, + anti-tumor necrosis factor- $\alpha$ (TNF) antibody; lane 8 , stimulated with recombinant TNF (200 U/ $\mathrm{ml}$ ); and lane 9 , as lane 8 , but in the presence of anti-TNF antibody.

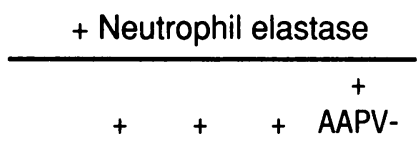

Rest Alone SLPI $\alpha 1$ AT PMSF CMK

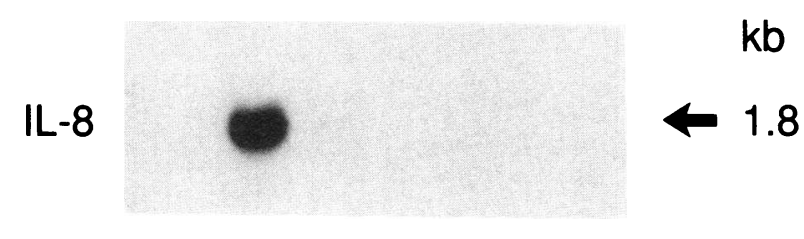

$\beta$-actin

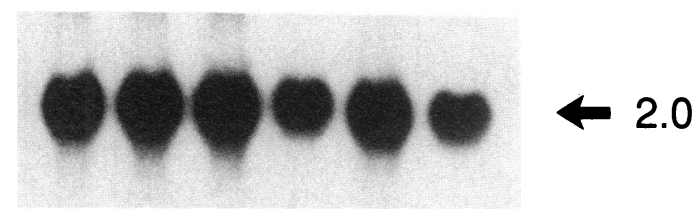

$\begin{array}{llllll}1 & 2 & 3 & 4 & 5 & 6\end{array}$

Figure 4. Induction of IL-8 gene expression in human bronchial epithelial BET-1A cells by NE. Shown are Northern analyses of RNA $\left(10 \mu \mathrm{g} /\right.$ lane) hybridized with ${ }^{32} \mathrm{P}$-labeled IL-8 probe (top) and $\beta$-actin probe (bottom). The size of mRNA transcripts are indicated. Lane 1 , resting cells; lane 2, cells incubated with $\mathrm{NE}(10 \mathrm{nM})$ for $3 \mathrm{~h}, 37^{\circ}$; lane 3, identical to lane 2, but in the presence of recombinant SLPI; lane 4, as lane $2+\alpha 1$-antitrypsin ( $\alpha 1 \mathrm{AT})$; lane 5, as lane $2+\mathrm{PMSF}$; and lane 6, + AAPV-CMK.

Neutrophil chemotactic activity released from neutrophil elastase-stimulated bronchial epithelial cells. As previously described $(25-28,49)$, recombinant IL-8 was strongly chemotactic for neutrophils and this ability was blocked by an anti-IL-8 antibody (Fig. 6). Culture supernatants from resting BET-1A cells displayed very little chemotactic activity for neutrophils. NE itself did not have chemotactic activity (not shown). In contrast, supernatants from NE-stimulated BET-1A cells
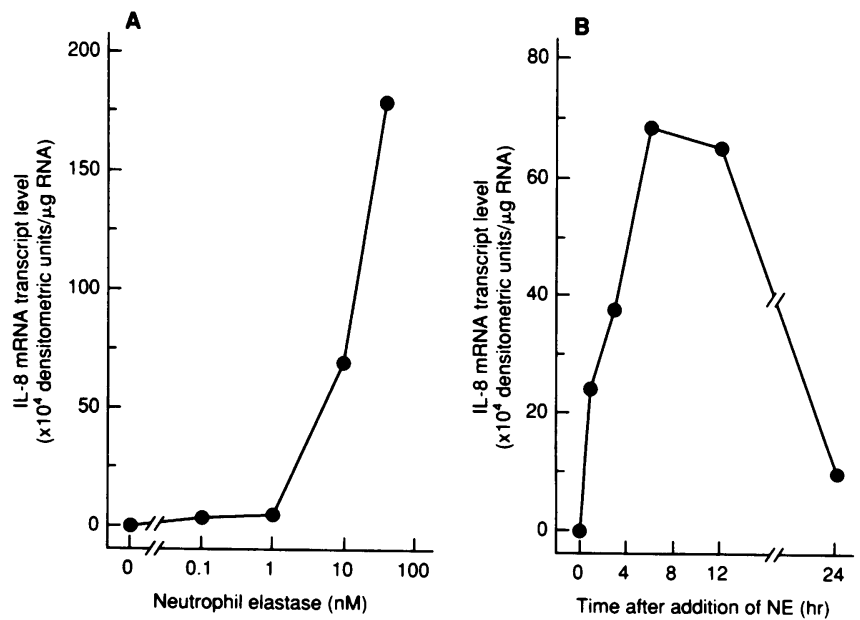

Figure 5. IL-8 mRNA levels in BET-1A human bronchial epithelial cells induced by NE. $(A)$ expression of IL- 8 mRNA in response to increasing dose of NE in BET-1A cells. $(B)$ Time course of IL-8 mRNA expression by BET-1A cells after exposure to NE (10 nM). Data shown in both panels are a representative of two individual experiments. 


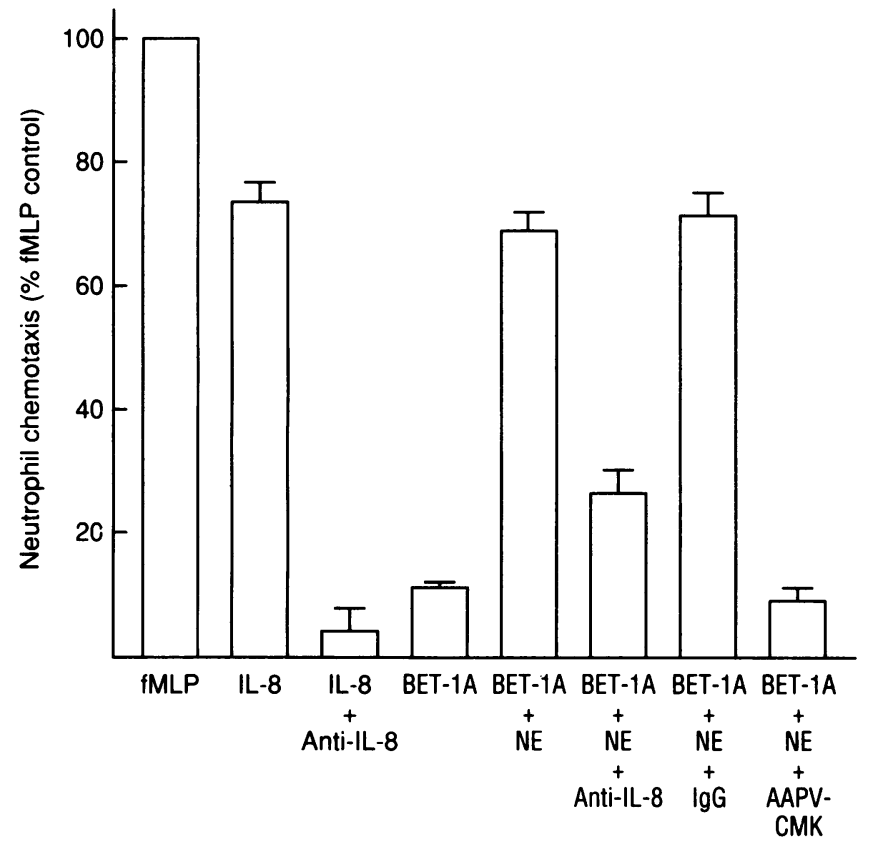

Figure 6. IL-8-related neutrophil chemotactic activity released by BET-1A human bronchial epithelial cells following stimulation with NE. Supernatants were collected from BET-1A cells incubated for $24 \mathrm{~h}, 37^{\circ}$ and evaluated for the presence of neutrophil chemotactic activity using a modified Boyden chamber. Shown are data for: FMLP (used as a positive control $=100 \%$ activity); IL-8; IL-8 incubated with anti-IL-8 antibody; resting BET-1A cells; BET-1A cells incubated with NE; anti-IL-8 antibody added to the supernatant of BET-1A cells incubated with NE; irrelevant IgG antibody added to the supernatant of BET-1A cells incubated with NE; and BET-1A cells incubated with NE + NE inhibitor AAPV-CMK. Data shown represent triplicate assay determinations of one example of three different experiments.

showed neutrophil chemotactic activity that was suppressed by anti-IL-8 antibody but not by preimmune rabbit IgG. Further, the addition of the NE-specific inhibitor AAPV-CMK in amounts sufficient to inhibit NE prevented NE from inducing BET-1A cells to release the neutrophil chemotactic activity. The results from the neutrophil chemotactic activity assay of CF ELF were uninterpretable because it was unclear how much of the total chemotactic activity in CF ELF was due to IL-8 as neutrophil migration was affected by the complex mixture of mediators, serum, bacterial, and intracellular components from damaged cells in the ELF of CF individuals.

Modulation of IL-8 gene expression in bronchial epithelial cells by neutrophil elastase. Isolated nuclei from resting BET1 A cells demonstrated a very low rate of IL-8 gene transcription (Fig. 7, lane 1). However, following stimulation with NE, the IL-8 gene transcription rate increased markedly over the resting level. Importantly, this upregulation of IL-8 gene transcription was blocked by $\alpha 1 \mathrm{AT}$ (lane 3) and by SLPI (not shown). In contrast, the transcription rate of the c-myc gene or $\beta$-actin gene changed very little with NE stimulation $(850 \%$ increase for IL-8 gene with NE compared with a $115 \%$ change for $c-m y c$ and a $160 \%$ change for $\beta$-actin).

The addition of NE to BET-1A cells did not change the stability of the IL-8 mRNA transcripts (Fig. 8). In this regard, following the inhibition of RNA synthesis with actinomycin D,

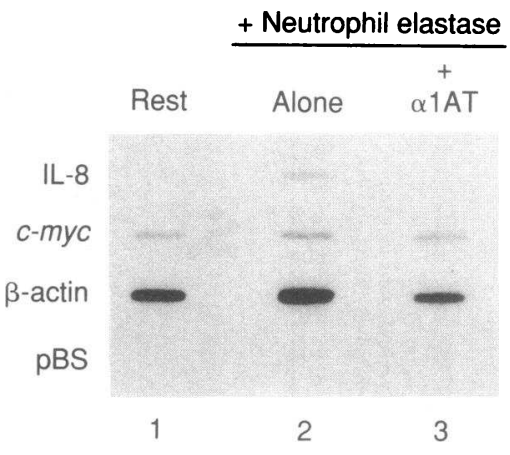

Figure 7. Modulation of the relative rate of IL-8 gene transcription in BET-1A human bronchial epithelial cells by NE. BET-1A cells were incubated $\left(3 \mathrm{~h}, 37^{\circ}\right)$ : lane 1 , at rest; lane 2 , in the presence of NE; and lane 3 , as lane 2 but $+\alpha 1$-antitrypsin $(\alpha 1 A T)$. Shown are autoradiograms of ${ }^{32} \mathrm{P}$-labeled nuclear RNA hy-

bridized to probes for IL-8, c-myc, $\beta$-actin, and an irrelevant plasmid, pBluescript II SK+ $(p B S)$.

IL-8 mRNA levels fell rapidly in resting BET-1A cells. The same pattern was observed in BET-1A cells exposed to NE. In contrast, in the presence of cycloheximide, the stability of IL-8 mRNA transcripts was markedly increased.

\section{Discussion}

Cystic fibrosis is characterized by chronic airway infection and inflammation invariably dominated by neutrophils. Although critical to host defense, neutrophils cause progressive damage to the airway epithelium by virtue of their potent mediators, most significantly NE, a destructive proteolytic enzyme (1, 10$19,50,51)$. Not only can NE damage epithelial cells by direct proteolytic effects, but also can hinder normal host defense by interfering with ciliary clearance, increasing mucus production, cleaving immunoglobulin and complement, and by impairing phagocytosis and killing of Pseudomonas aeruginosa by neutrophils $(16,17,52-56)$. The present study demonstrates that the fluid lining the respiratory epithelium in CF contains large numbers of neutrophils and active $\mathrm{NE}$, and that the $\mathrm{NE}$ in CF ELF is capable of inducing bronchial epithelial cells to express the gene for IL-8 and release neutrophil chemotactic activity as properties of IL-8.

BET-1A bronchial epithelial cells are transformed human bronchial epithelial cells. In the context that IL-8 is a potent neutrophil chemoattractant and activator (26-28), these obser-

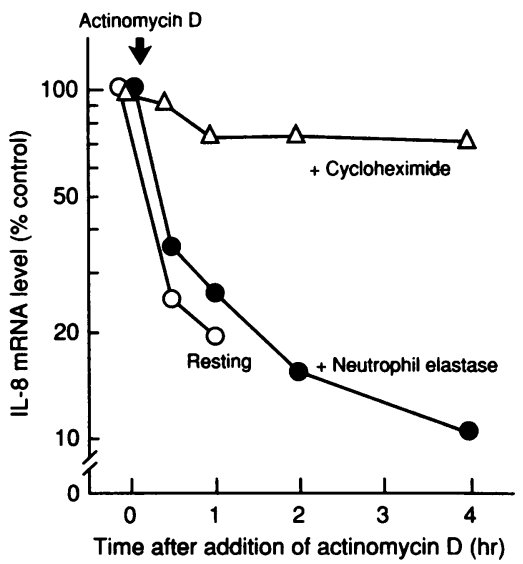

Figure 8 . Stability of IL-8 mRNA transcripts in BET-1A human bronchial epithelial cells at rest or following stimulation with NE. Shown are IL-8 mRNA levels (presented as $100 \%$ starting level) following the addition of actinomycin $\mathrm{D}$. The BET-1A cells were incubated $\left(3 \mathrm{~h}, 37^{\circ}\right)$ alone or in the presence of NE before actinomycin $D$ was added. As a control, parallel cultures of BET-1A cells were evaluated after incubation with cycloheximide (3 $\mathrm{h}, 37^{\circ}$ ). Data are representative of two individual experiments. 
vations, while made using a transformed bronchial cell line, likely represent the in vivo situation as evidenced by the absence of IL-8 from ELF of normal individuals and its presence in CF ELF at levels ranging from 8 to $108 \mathrm{nM}$, well above the usual IC ${ }_{50}$ for neutrophil responses to IL-8 (57). They suggest a scenario on the respiratory epithelium in CF, in which $\mathrm{NE}$ released by neutrophils induces bronchial epithelial cells to release IL-8, and the IL-8 recruits neutrophils that release NE, perpetuating the process.

While this succession of processes helps to explain the chronicity of neutrophil-dominated airway inflammation in CF in the absence of infection (and thus the chronic progressive airway damage), it begs the question as to what initiates the recruitment of the neutrophils. The answer to this is not known, but there are a number of possibilities, including normal host defense processes, such as those mediated by alveolar macrophages and/or complement $(14,20-24)$. Consistent with this concept, IL-8 mRNA transcripts have been observed in inflammatory cells recovered by lavage in CF, and IL-8 detected in CF ELF (58). Further, while the induction of IL-8 gene expression in bronchial epithelial cells by CF ELF is completely blocked by NE-inhibitors, it remains possible that other mediators may contribute to this process. In this regard, CF ELF contains a variety of other mediators, including TNF, interleukin-1, metalloproteinase, and Pseudomonas elastase (15, 59-61). In addition, the presence of large numbers of neutrophils in CF ELF suggests that, in addition to NE, other neutrophil performed mediators such as myeloperoxidase, collagenase, gelatinase, and proteinase 3 may also be present $(13,50)$. It is also possible that the bronchial epithelium may release chemoattractants other than IL-8 (62-64). Thus, while NE appears to be a major signal for bronchial epithelial IL-8 gene expression in CF ELF, it is not necessarily the only signal and IL-8 expression is not necessarily the only response of the bronchial epithelium to the burden of inflammatory mediators it likely encounters.

$\mathrm{NE}$ induces an increase in the relative rate of transcription of the IL-8 gene in bronchial epithelial cells, but does not influence IL-8 mRNA transcript stability, suggesting the transcriptional process dominates in the response. However, the intracellular mechanisms of NE induction of IL-8 gene expression in bronchial epithelial cells are unknown. NE interacts with mononuclear phagocytes through a receptor on the surface of these cells (65), and can induce the release of glycoconjugates and sulfated macromolecules by bronchial epithelial cells (55, 66); this process might be linked to the same signal transduction pathway(s) to induce IL-8 gene expression.

Independent of the mechanisms involved, in the context that there are abundant neutrophils and NE in CF ELF, that NE induces IL-8 gene expression in human bronchial epithelial cells, that IL-8 is a potent chemoattractant and activator of neutrophils, and that inhibitors of NE suppress the ability of NE to induce IL-8 gene expression in bronchial epithelium, our observations suggest that local anti-NE therapy of CF may not only protect the epithelium from NE (12), but may also dampen the exaggerated recruitment of neutrophils to the lung in this disease. In this context, while caution must be used in not interfering with the necessity of neutrophils in the local host defense process, it is reasonable to suggest that anti-NE therapy, probably by direct aerosol administration, should be evaluated as a means of limiting the neutrophil-dominated airway inflammation in this disorder.

\section{Acknowledgments}

We thank Dr. L. Chang-Stroman, Pulmonary Branch, National Heart, Lung, and Blood Institute, for helping in this study, and T. Raymer for editorial assistance.

\section{References}

1. Boat, T. F., M. J. Welsh, and A. L. Beaudet. 1989. Cystic fibrosis. In The Metabolic Basis of Inherited Diseases. C. R. Scriver, A. L. Beaudet, W. S. Sly, and D. Valle, editors. 6th edition. McGraw-Hill Inc., New York. 2649-2680.

2. Rommens, J. M., M. C. Iannuzzi, B.-S. Kerem, M. L. Drumm, G. Melmer, M. Dean, R. Rozmahel, J. L. Cole, D. Kennedy, N. Hidaka, et al. 1989. Identification of the cystic fibrosis gene: chromosome walking and jumping. Science (Wash. DC). 245:1059-1065.

3. Riordan, J. R., J. M. Rommens, B.-S. Kerem, N. Alon, R. Rozmahel, Z. Grzelczak, J. Zielenski, S. Lok, N. Plavsic, J.-L. Chou, et al. 1989. Identification of the cystic fibrosis gene: cloning and characterization of complementary DNA. Science (Wash. DC). 245:1066-1073.

4. Kerem, B.-S., J. M. Rommens, J. A. Buchanan, D. Markiewicz, T. K. Cox, A. Chakravarti, M. Buchwald, and L.-C. Tsui. 1989. Identification of the cystic fibrosis gene: genetic analysis. Science (Wash. DC). 245:1073-1080.

5. Cheng, S. H., R. J. Gregory, J. Marshall, S. Paul, D. W. Souza, G. A. White, C. R. O'Riordan, and A. E. Smith. 1990. Defective intracellular transport and processing of CFTR is molecular basis of most cystic fibrosis. Cell. 63:827-834.

6. Quinton, P. M. 1990. Cystic fibrosis: a disease in electrolyte transport. FASEB (Fed. Am. Soc. Exp. Biol.) J. 4:2709-2717.

7. Welsh, M. J. 1990. Abnormal regulation of ion channels in cystic fibrosis epithelia. FASEB (Fed. Am. Soc. Exp. Biol.) J. 4:2718-2725.

8. Anderson, M. P., D. P. Rich, R. J. Gregory, A. E. Smith, and M. J. Welsh. 1991. Generation of cAMP-activated chloride currents by expression of CFTR. Science (Wash. DC). 251:679-682.

9. Kartner, N., J. W. Hanrahan, T. J. Jensen, A. L. Naismith, S. Sun, C. A. Ackerley, E. F. Reyes, L.-C. Tsui, J. M. Rommens, C. E. Bear, and J. R. Riordan. 1991. Expression of the cystic fibrosis gene in non-epithelial invertebrate cells produces a regulated anion conductance. Cell. 64:681-691.

10. Goldstein, W., and G. Döring. 1986. Lysosomal enzymes from polymorphonuclear leukocytes and proteinase inhibitors in patients with cystic fibrosis. Am. Rev. Respir. Dis. 134:49-56.

11. Elborn, J. S., and D. J. Shale. 1990. Lung injury in cystic fibrosis. Thorax. 45:970-973.

12. McElvaney, N. G., R. C. Hubbard, P. Birrer, M. S. Chernick, D. B. Caplan, M. M. Frank, and R. G. Crystal. 1991. Aerosol $\alpha 1$-antitrypsin treatment for cystic fibrosis. Lancet. 337:392-394.

13. Abramson, S. L., H. L. Malech, and J. I. Gallin. 1991. Neutrophils. In The Lung. R. G. Crystal and J. B. West, editors. Scientific Foundations. Raven Press, Ltd., New York. 157-167.

14. Sibille, Y., and H. Y. Reynolds. 1990. Macrophages and polymorphonuclear neutrophils in lung defense and injury. Am. Rev. Respir. Dis. 141:471-501.

15. Suter, S. 1989. The imbalance between granulocyte neutral proteases and antiproteases in bronchial secretions from patients with cystic fibrosis. In Pseudomonas aeruginosa Infection. N. Høiby, S. S. Pedersen, G. H. Shand, G. Döring, and I. A. Holder. Antibiot. Chemother. (Basel). 42:158-168.

16. Berger, M., R. J. Sorensen, M. F. Tosi, D. G. Dearborn, and G. Döring. 1989. Complement receptor expression on neutrophils at an inflammatory site, the Pseudomonas aeruginosa infected lung in cystic fibrosis. J. Clin. Invest. 84:1302-1313.

17. Tosi, M. F., H. Zakem, and M. Berger. 1990. Neutrophil elastase cleaves C3bi on opsonized Pseudomonas as well as CRI on neutrophils to create a functionally important opsonin receptor mismatch. J. Clin. Invest. 86:300-308.

18. Tomashefski, J. F., Jr., M. Bruce, H. I. Goldberg, and D. G. Dearborn. 1986. Regional distribution of macroscopic lung disease in cystic fibrosis. Am. Rev. Respir. Dis. 133:535-540.

19. Bruce, M., L. Poncz, J. D. Klinger, R. C. Stern, J. F. Tomashefski, Jr., and D. G. Dearborn. 1985. Biochemical and pathologic evidence for proteolytic destruction of lung connective tissue in cystic fibrosis. Am. Rev. Respir. Dis. 132:529-535.

20. Crystal, R. G. 1991. Alveolar macrophages. In The Lung. R. G. Crystal and J. B. West, editors. Scientific Foundations. Raven Press, Ltd., New York. 527-538.

21. Senior, R. M., and C. C. Daughaday. 1991. Chemotaxis. In The Lung. R. G. Crystal and J. B. West, editors. Scientific Foundations. Raven Press, Ltd., New York. 131-139.

22. Perlmutter, D. H., R. C. Strunk, and H. R. Colten. 1991. Complement. In The Lung. R. G. Crystal and J. B. West, editors. Scientific Foundations. Raven Press, Ltd., New York. 511-525. 
23. Rankin, J. A., I. Sylvester, S. Smith, T. Yoshimura, and E. J. Leonard. 1990. Macrophages cultured in vitro release leukotriene $B_{4}$ and neutrophil attractant/activation protein (interleukin 8) sequentially in response to stimulation with lipopolysaccharide and zymosan. J. Clin. Invest. 86:1556-1564.

24. Fick, R. B., Jr., R. V. Robbins, S. U. Squier, R. A. Robbins, W. E. Schoderbek, and W. O. Russ. 1986. Complement activation in cystic fibrosis respiratory fluids: in vivo and in vitro generation of $\mathrm{C} 5 \mathrm{a}$ and chemotactic activity. Pediatr. Res. 20:1258-1268.

25. Nakamura, H., K. Yoshimura, H. A. Jaffe, and R. G. Crystal. 1991. Interleukin-8 gene expression in human bronchial epithelial cells. J. Biol. Chem. 266:19611-19617.

26. Baggiolini, M., A. Walz, and S. L. Kunkel. 1989. Neutrophil-activating peptide-1/interleukin 8, a novel cytokine that activates neutrophils. J. Clin. Invest. $84: 1045-1049$.

27. Matsushima, K., and J. J. Oppenheim. 1989. Interleukin 8 and MCAF: novel inflammatory cytokines inducible by IL-1 and TNF. Cytokines. 1:2-13

28. Leonard, E. J., and T. Yoshimura. 1990. Neutrophil attractant/activation protein-1 (NAP-1[interleukin-8]). Am. J. Respir. Cell Mol. Biol. 2:479-486.

29. Fulmer, J. D., W. C. Roberts, E. R. von Gal, and R. G. Crystal. 1977. Small airways in idiopathic pulmonary fibrosis. J. Clin. Invest. 60:595-610.

30. Shwachman, H., and L. L. Kulczycki. 1958. Long-term study of one hundred five patients with cystic fibrosis. Am. J. Dis. Child. 96:6-15.

31. Saltini, C., A. J. Hance, V. J. Ferrans, F. Basset, P. B. Bitterman, and R. G. Crystal. 1984. Accurate quantification of cells recovered by bronchoalveolar lavage. Am. Rev. Respir. Dis. 130:650-658.

32. Rennard, S. I., G. Basset, D. Lecossier, K. M. O'Donnell, P. Pinkston, P. G. Martin, and R. G. Crystal. 1986. Estimation of volume of epithelial lining fluid recovered by lavage using urea as marker of dilution. J. Appl. Physiol. 60:532-538.

33. Wewers, M. D., A. M. Casolaro, S. E. Sellers, S. C. Swayze, K. M. McPhaul, J. T. Wittes, and R. G. Crystal. 1987. Replacement therapy for alpha antitrypsin deficiency associated with emphysema. N. Engl. J. Med. 316:10551062.

34. Reddel, R. R., Y. Ke, B. I. Gerwin, M. G. McMenamin, J. F. Lechner, R. T. Su, D. E. Brash, J.-B. Park, J. S. Rhim, and C. C. Harris. 1988. Transformation of human bronchial epithelial cells by infection with SV40 or adenovirus-12 SV40 hybrid virus, or transfection via strontium phosphate coprecipitation with a plasmid containing SV40 early region genes. Cancer Res. 48:1904-1909.

35. Lechner, J. F., and M. A. LaVeck. 1985. A serum-free method for culturing normal human bronchial epithelial cells at clonal density. J. Tissue Culture Methods. 9:43-48.

36. Ausubel, F. M., R. Brent, R. E. Kingston, O. D. Moore, J. A. Smith, J. G. Seidman, and K. Struhl. 1987. Analysis of RNA by Northern hybridization. In Current Protocols in Molecular Biology. John Wiley \& Sons, Inc., New York. 4.9.1.-4.9.8.

37. Trapnell, B. C., P. L. Zeitlin, C.-S. Chu, K. Yoshimura, H. Nakamura, W. B. Guggino, J. Bargon, T. C. Banks, W. Dalemans, A. Pavirani, J.-P. Lecocq and R. G. Crystal. 1991. Down-regulation of cystic fibrosis mRNA transcrip levels and induction of the cystic fibrosis chloride secretory phenotype in epithelial cells by phorbol ester. J. Biol. Chem. 266:10319-10323.

38. Chirgwin, J. M., A. E. Przybyla, R. J. MacDonald, and W. J. Rutter. 1978. Isolation of biologically active ribonucleic acid from sources enriched in ribonuclease. Biochemistry. 18:5294-5299.

39. Church, G. M., and W. Gilbert. 1984. Genomic sequencing. Proc. Natl. Acad. Sci. USA. 81:1991-1995.

40. Feinberg, A. P., and B. Vogelstein. 1983. A technique for radiolabeling DNA restriction endonuclease fragments to high specific activity. Anal. Biochem. 132:6-13.

41. Schmid, J., and C. Weissmann. 1987. Induction of mRNA for a serine protease and a $\beta$-thromboglobulin-like protein in mitogen-stimulated human leukocytes. J. Immunol. 139:250-256.

42. Matsushima, K., K. Morishita, T. Yoshimura, S. Lavu, Y. Kobayashi, W. Lew, E. Appella, H. F. Kung, E. J. Leonard, and J. J. Oppenheim. 1987. Molecular cloning of cDNA for a human monocyte derived neutrophil chemotactic factor (MDNCF) and the induction of MDNCF mRNA by interleukin-1 and tumor necrosis factor. J. Exp. Med. 167:1883-1893.

43. Saiki, R. K., D. H. Gelfand, S. Stoffel, S. J. Scharf, R. Higuchi, G. T. Horn, K. B. Mullis, and H. A. Erlich. 1988. Primer-directed enzymatic amplification of DNA with a thermostable DNA polymerase. Science (Wash. DC). 239:487-491

44. Gunning, P., P. Ponte, H. Okayama, J. Engel, H. Blau, and L. Kedes. 1983. Isolation and characterization of full-length cDNA clones for human $\alpha-, \beta$ and $\gamma$-actin mRNAs: skeletal but not cytoplasmic actins have an amino-terminal cysteine that is subsequently removed. Mol. Cell. Biol. 3:787-795.
45. Harvath, L., W. Falk, and E. J. Leonard. 1980. Rapid quantitation of neutrophil chemotaxis: use of a polyvinylpyrrolidone-free polycarbonate membrane in a multiwell assembly. J. Immunol. Methods. 37:39-45.

46. Ferrante, A., and Y. H. Thong. 1982. Separation of mononuclear and polymorphonuclear leukocytes from human blood by one-step Hypaque-Ficoll method is dependent of blood column height. J. Immunol. 48:81-85.

47. Yoshimura, K., H. Nakamura, B. C. Trapnell, W. Dalemans, A. Pavirani, J.-P. Lecocq, and R. G. Crystal. 1991. The cystic fibrosis gene has a "housekeeping"-type promoter and is expressed at low levels in cells of epithelial origin. $J$. Biol. Chem. 266:9140-9144.

48. Chomczynski, P., and N. Sacchi. 1987. Single-step method of RNA isolation by acid guanidinium thiocyanate-phenol-chloroform extraction. Anal. Bio chem. 162:156-159.

49. Lindley, I., H. Aschauer, J.-M. Seifert, C. Lam, W. Brunowsky, E. Kownatzki, M. Thelen, P. Peveri, B. Dewald, V. von Tscharner, et al. 1990. Synthesis and expression in Escherichia coli of the gene encoding monocyte-derived neutrophil-activating factor: biological equivalence between natural and recombinant neutrophil-activating factor. Proc. Natl. Acad. Sci. USA. 85:9199-9203.

50. Hubbard, R. C., and R. G. Crystal. 1991. Proteases. In The Lung. R. G. Crystal and J. B. West, editors. Scientific Foundations. Raven Press, Ltd., New York. 157-167.

51. Travis, J., P. J. Giles, L. Porcelli, C. F. Reilly, R. Baugh, and J. Powers. 1980. Human leucocyte elastase and cathepsin G: structural and functional characteristics. In Protein Degradation in Health and Disease. D. Evered and J. Whelan, editors. Ciba Foundation Symposium 75, Amsterdam. 51-68.

52. Lucey, E. C., P. J. Stone, T. G. Christensen, R. Breuer, and G. L. Snider. 1988. An 18-month study of the effects on hamster lungs of intratracheally administered human neutrophil elastase. Exp. Lung Res. 14:671-686.

53. Janoff, A. 1985. Elastase in tissue injury. Annu. Rev. Med. 36:207-216.

54. Smallman, L. A., S. L. Hill, and R. A. Stockley. 1984. Reduction of ciliary beat frequency in vitro by sputum from patients with bronchiectasis: a serine proteinase effect. Thorax. 39:663-667.

55. Sommerhoff, C. P., J. A. Nadel, and C. B. Basbaum. 1990. Neutrophil elastase and cathepsin $\mathrm{G}$ stimulate secretion from cultured bovine airway gland serous cells. J. Clin. Invest. 85:682-689.

56. Fick, R. B., G. P. Naegel, S. Squier, R. E. Wood, J. B. L. Gee, and H. Y. Reynolds. 1984. Proteins of the cystic fibrosis respiratory tract: fragmented immunoglobulin $\mathrm{G}$ opsonic antibody causing defective opsonophagocytosis. J. Clin. Invest. 74:236-248.

57. Hebert, C. A., F. W. Luscinskas, J. M. Kiely, E. A. Luis, W. C. Darbonne G. L. Bennett, C. C. Liu, M. S. Obin, M. A. Gimbrone, and J. B. Baker. 1990 Endothelial and leukocyte forms of IL-8. Conversion by thrombin and interactions with neutrophils. J. Immunol. 145:3033-3040.

58. Fick, R. B., T. J. Standiford, S. L. Kunkel, and R. M. Strieter. 1991. Interleukin-8 and neutrophil accumulation in the inflammatory airways disease of cystic fibrosis. Clin. Res. 39:292A. (Abstr.)

59. Fick, R. B., Jr., and R. N. Shaw. 1990. Inhibition of immunoreactive tumor necrosis factor and attenuation of macrophage lipopolysaccharide response in chronic Pseudomonas lung infections. Clin. Res. 38:439A. (Abstr.)

60. Fick, R. B., D. B. Hornick, and S. I. Rennard. 1987. Contribution of Pseudomonas elastase to the protease burden in cystic fibrosis airways. Clin. Res. 35:533A. (Abstr.)

61. Döring, G., H.-J. Obernesser, K. Botzenhart, B. Flehmig, N. Høiby, and A. Hofmann. 1983. Proteases of Pseudomonas aeruginosa in patients with cystic fibrosis. J. Infect. Dis. 147:744-750.

62. Rennard, S. I., J. D. Beckmann, and R. A. Robbins. 1991. Biology of airway epithelial cells. In The Lung. R. G. Crystal and J. B. West, editors. Scientific Foundations. Raven Press, Ltd., New York. 157-167.

63. Shoji, S., R. F. Ertl, and S. I. Rennard. 1987. Cigarette smoke stimulates release of neutrophil chemotactic activity from cultured bronchial epithelial cells. Clin. Res. 35:539A. (Abstr.)

64. Koyama, S., S. I. Rennard, and R. A. Robbins. 1991. Antiproteases attenuate the cigarette smoke induced release of neutrophil chemotactic activity from bronchial epithelial cells. Am. Rev. Respir. Dis. 143:325A. (Abstr.)

65. Campbell, E. J. 1982. Human leukocyte elastase, cathepsin G, and lactoferrin: family of neutrophil granule glycoproteins that bind to an alveolar macrophage receptor. Proc. Natl. Acad. Sci. USA. 79:6941-6945.

66. Breuer, R., T. G. Christensen, R. M. Niles, P. J. Stone, and G. L. Snider. 1989. Human neutrophil elastase causes glycoconjugate release from the epithelial cell surface of hamster trachea in organ culture. Am. Rev. Respir. Dis. 139:779-782. 